\title{
Importance of wheat stem rust (Puccinia graminis f.sp. tritici) in Guji zone, Southern Ethiopia
}

\author{
Tolessa Taye ${ }^{1}$, Chemada Fininsa ${ }^{2}$, Getaneh Woldeab ${ }^{3}$ \\ ${ }^{1}$ Oromia Agricultural Research Institute Yabello Pastoral and Dry Land Agricultural Research Centre, Yabello \\ ${ }^{2}$ Haramaya University, Dire Dawa, Ethiopia \\ ${ }^{3}$ Ethiopia institute of Agricultural research Ambo Plant Protection Research Centre, Ambo Ethiopia
}

\section{Email address:}

tolessataye1@gmail.com (T. Taye), chefigu@yahoo.com (C. Fininsa), getanehwoldeab@gmail.com (G. Woldeab)

\section{To cite this article:}

Tolessa Taye, Chemada Fininsa, Getaneh Woldeab. Importance of Wheat Stem Rust (Puccinia Graminis F.Sp. Tritici) in Guji Zone, Southern Ethiopia. Plant. Vol. 2, No. 1, 2013, pp. 1-5. doi: 10.11648/j.plant.20140201.11

\begin{abstract}
Wheat (Triticum spp) is the most important cereals in Ethiopia, is threatened by abiotic and biotic constraints. Among the biotic, stem rust (Puccinia graminis f.sp. tritici) is one of the major limitations of wheat production. Information on the occurrence and reaction of cultivars to stem rust in Guji zone was unknown. Survey was conducted in Bore, Damma and Ana Sora districts of Guji zone to assess the prevalence, incidence and severity of wheat stem rust in 2011 growing season. During the survey work, 77 wheat fields in 17 Peasant associations of the three districts of Guji zone were assessed. The result of survey revealed that all the wheat fields were affected by stem rust in all the surveyed area. Incidences greater than $22.72 \%$ and lesser than 20\% were recorded in Damma and Bore districts, respectively. Stem rust severity ranged from 18.16 to $27.39 \%$ in all the surveyed districts. The survey work showed that wheat stem rust was serious disease of wheat in the zones and may cause high economic loss if the susceptible local cultivars and Kubsa were continued to be grown in the area.
\end{abstract}

Keywords: Wheat Stem Rust Bore, Damma and Aana Sora

\section{Introduction}

Bread wheat (Triticum aestivum L. em. Thell) is the world's leading cereal grain where more than one-third of the population of the world uses as a staple food (Curtis, 2002). It is one of the most important cereal crops of Ethiopia (Hailu et al., 1991; Bekele et al., 1999). It ranked third in land coverage and total production after tef and maize and in productivity after maize and sorghum (CSA, 2010). Wheat is produced across a wide range of agroecological and crop management regime (Belay and Tanners, 1999). The most suitable area for wheat production falls between 1900-2700 m.a.s.l (Hailu et al., 1991). Despite the large area under wheat in Ethiopia the national average yield is $1.83 \mathrm{t} / \mathrm{ha}$ (CSA, 2010), which is far below the average of African and world yield productivity. This probably wheat is attacked by a number of diseases that cause great losses to the quality and quantity of produce. Among this rusts are the most important disease of wheat worldwide, inspite of great progress made in their control in many countries (Saari and Prescot, 1985). Rusts are the major disease of wheat since no other wheat disease could result in greater loss over large area in a given year (Loegering et al., 1967; Amanuel, 1994). Rusts can cause up to 60 percent of yield loss for leaf or stripe (yellow) rust and 100 percent loss for stem rust (Park et al., 2007). The persistence of rust as a significant disease in wheat can be attributed to specific characteristics of the rust fungi. These characteristics include a capacity to produce a large number of spores which can be wind-disseminated over long distances and infect wheat under favorable environmental conditions and the ability to change genetically, thereby producing new races with increased aggressiveness on resistant wheat cultivars.

Stem or black rust of wheat caused by the fungus Puccinia graminis f. sp. tritici Ericks and Henn (Pgt) is an important disease on wheat worldwide. It is an obligate biotroph, heteroceous in its life cycle and heterothallic in mating type (Alexopoulos et al., 1996). It is known to bear many physiologic races generated mainly by mutation (Roelfs, 1985). Ethiopia is one of the hot spot areas for the development of the present wheat stem rust complex (Leppik, 1970). In Guji highland wheat is highly exposed to wheat stem rust damage. This most probable farmer of the area is used the most susceptible wheat cultivar like 
Kubsa and most of the farmer use the late sown season this usually coincide with condition suitable for wheat stem rust and currently the barley will replacing the farm in most of the case.

Therefore, in the present work, wheat stem rust was studied in a more specific and intensive way in three districts of Guji zone of southern Oromia Regional State. These districts represent potential wheat production areas in the zone. So far little or no efforts have been made to identify the most affected areas in the zone, and quantifying of the disease occurrence, hence this work gears the information gap of stem rust that remains unknown for a long period of time in the zone. Therefore, the present research aims:

To asses' distribution, incidence and severity of wheat stem rust in Guji, Oromia.

\section{Materials and Methods}

\subsection{Description of the Study Area}

This study consisted of wheat stem rust (Puccinia graminis f.sp. tritici) survey and evaluation of wheat cultivars for slow rusting resistance. The wheat stem rust assessment survey was conducted in three districts of Guji zone namely Bore, Ana Sora and Damma. The annual mean minimum and maximum temperature of the area is $15^{\circ} \mathrm{C}$ and $25^{\circ} \mathrm{C}$, respectively, while, the minimum and the maximum annual rainfall is $1450 \mathrm{~mm}$ and $2900 \mathrm{~mm}$ respectively. The minimum and maximum temperature recorded during growing season of 2011 was $16.5^{\circ} \mathrm{c}$ and $20.3^{\circ} \mathrm{c}$, while the minimum and maximum rainfall recorded in Bore during this season was $4.2 \mathrm{~mm}$ and $239.8 \mathrm{~mm}$ respectively.

\subsection{Wheat Stem Rust Survey}

Stem rust survey was conducted in three districts of Guji zone during main seasons of 2011 and short season of 2011 in few districts of southern oromia regional state. The three districts had mid highland (1500-2300 m.a.s.l) and highland (2301-3200 m.a.s.l) agro-ecologies. This makes the area suitable for wheat production. Unfortunately altitude below 2300 m.a.s.l was not covered during the survey work. The survey was conducted in 17 peasant associations (PA) and 77 fields in the three districts of the zone. Stratified sampling technique was applied in the survey. PAs were randomly selected from each district and based on the representativeness of wheat production of the area. As a result, 6 PAs were assessed from each district except in Bore district where 5 PAs were assessed because in the 6th PA there were no wheat fields available. In this area wheat production was stopped due to the occurrence of heavy rust epidemics which result in high yield loss for the last three consecutive years. The stem rust assessment was made along the two diagonals (in an " $\mathrm{X}$ " pattern) of the field from five points using $0.5 \mathrm{mX} 0.5 \mathrm{~m}(0.25 \mathrm{~m} 2)$ quadrants. In each field plants within the quadrates were counted and recorded as diseased/infected and healthy/non-infected and the different parameters were measured as follows.

Disease incidence (DI) was the proportion of stem rust infected plants to the total number of plants in the quadrate and it is calculated as:

$$
D I=\frac{\text { Number of diseased plant } \times 100}{\text { total number of plant in qudrate }}
$$

Disease Severity: was expressed as the percentage or proportion of plant area affected by wheat stem rust disease. More often, disease assessment scales were used to express the relative proportions of affected tissue at a particular point in time. The disease severity under field conditions was recorded as percentage of leaf/stem area covered by rust following modified Cobb's scale as developed by Peterson et al. (1948). According to this scale, at $100 \%$ disease severity, the actual leaf area covered by rust pustules is $37 \%$.Disease severity was assessed by selecting 10 plants from a single quadrate and five quadrates were used for the estimation of disease severity from a single wheat field, finally the average severity was taken for the analysis.

Percentage of severity index (PSI) was calculated by using the following formula Wheelers (1969).

Other independent variables collected were

Altitude of the field in meters was estimated by using GPS

Date of planting was obtained by asking the farmer

Growth stage of the crop at time of assessment was obtained by visual observation using Zadoks scale.

Types of variety: was obtained by asking the farmers.

Agronomic practices such as number of cultivation, frequency of weeding, fertilizer use were collected by asking farmer.

All the parameters measured were analyzed by using descriptive statistical analysis over peasant associations, districts and altitude ranges.

\section{Results and Discussion}

\subsection{Importance of Wheat Stem Rust in Guji Zone}

Field survey was conducted in Guji zone in southern Oromia during 2011 main cropping season to assess the prevalence, incidence and severity of wheat stem rust and to determine the importance of the disease in the zone. In most of the areas, the survey was conducted at flowering to maturity growth stages of wheat. The survey work was conducted from 15-25 December 2012. The geographical locations of the surveyed areas were located in a range of longitude and latitude of $060.13865-06.27998 \mathrm{~N}$ and 038.73659-0380.83739E respectively.

\subsection{Disease Prevalence}

Prevalence of wheat stem rust was $100 \%$ in all the districts (Table 2). The most probable reasons for this might be the frequent use of local and susceptible improved cultivars in all of the surveyed areas. In addition to this, 
environmental condition may be suitable especially for late sown cultivars where early sown crops may serve as inoculum source in the areas. In all the surveyed areas the rainfall distribution was wide and bimodal near the surveyed area in the Borana lowlands and mid highland where the wheat planted two times in a year. This condition played significant role for continuous supply of inoculum for the Guji areas. If susceptible improved and local cultivars continue to grow it may not take a long time for the farmer to stop wheat production in the area. Currently in Bore and Damma wheat production was reduced from previously used area by $13.7 \%$ and $6.02 \%$, respectively because of the rust disease ( predominantly stem rust and yellow rust) causing high devastation on wheat (District office of Agriculture and Rural Development report) in the surveyed districts. In the majority of surveyed districts barley was replacing wheat.

\subsection{Disease Incidence}

The incidence of wheat stem rust in the fields was estimated for peasant associations (PA), districts and for the entire study area (Table 1 and 2). A total of 77 fields were surveyed in three districts of Guji zone. Incidence was ranging from $16.70-22.70 \%$. Incidence of $22.7 \%$ was recorded in Damma, followed by Ana Sora 17.5\% (Table 2). More than $56 \%$ of surveyed areas were categorized under low wheat stem rust incidence which was below $20 \%$. At PA level, the highest incidence of $30 \%$ was recorded in Eshidho Alleyo in Bore and Areda bala in Damma districts (Table 4), while the lowest incidence of 9.5\% was also recorded in Lettu PA in Bore district. About 57\% of the fields in Damma district, followed by $21.42 \%$ of the fields in Ana Sora district and $20.83 \%$ of the fields in Bore districts had incidence greater than $20 \%$ (Table 2). This study showed that wheat stem rust in all the districts was grouped under low incidence category which ranging from 0\%-20\% while severity was grouped under medium disease category which ranging from $21-40 \%$ disease severity (Table 2).The stem rust incidence of the zone showed that disease was relatively higher in damma district because in this area most of fields planted latter than the two districts.

Table 1. Wheat stem rust incidence and severity in the peasant associations of three districts of Guji zone during main season of 2011

\begin{tabular}{|c|c|c|c|c|}
\hline Districts & PA & No field assessed & Incidence & Severity \\
\hline \multirow[t]{7}{*}{ Bore } & Sorgo Baricha & 5 & 11.8 & 14.06 \\
\hline & Eshidho Alleyo & 5 & 30 & 31.25 \\
\hline & Kerra kepanno & 5 & 20.23 & 24.33 \\
\hline & Anno Kerrensa & 5 & 11.94 & 11.64 \\
\hline & Lettu & 4 & 9.54 & 9.52 \\
\hline & & & 16.70 & 18.16 \\
\hline & & & \pm 8.47 & \pm 9.26 \\
\hline \multirow[t]{8}{*}{ A.Sora } & Raya Boda & 5 & 20.5 & 31.23 \\
\hline & Roba Dabaye & 5 & 19.5 & 17.66 \\
\hline & Kelle & 4 & 23.3 & 26.24 \\
\hline & G/Gejaba & 4 & 15.9 & 35.9 \\
\hline & Hirba Bulliyo & 5 & 16.4 & 15.8 \\
\hline & Bube Korsa & 5 & 10.3 & 14.95 \\
\hline & & & \pm 17.5 & \pm 22.8 \\
\hline & & & \pm 4.3 & \pm 8.3 \\
\hline \multirow[t]{8}{*}{ Damma } & Hada Gurrati & 3 & 18.3 & 15.1 \\
\hline & Anole Sodo & 5 & 14.1 & 17.1 \\
\hline & Areda Bala & 5 & 30.0 & 21.7 \\
\hline & Duda Dera & 5 & 27.2 & 35.7 \\
\hline & Dugo Gutticha & 4 & 26.6 & 29.8 \\
\hline & Anfele & 3 & 20 & 45.1 \\
\hline & & & 22.7 & 27.4 \\
\hline & & & \pm 8.9 & \pm 10.3 \\
\hline
\end{tabular}

Table 2. Disease prevalence, incidence and severity of wheat stem rust in three districts of Guji zones during main season of 2011

\begin{tabular}{|c|c|c|c|c|c|c|c|c|c|c|c|c|c|c|c|}
\hline \multirow{2}{*}{ Districts } & \multirow{2}{*}{ Prev (\%) } & \multirow{2}{*}{ Inci (\%) } & \multirow{2}{*}{$\operatorname{Sev}(\%)$} & \multicolumn{6}{|c|}{ Disease category class } & \multicolumn{6}{|c|}{ Disease severity class } \\
\hline & & & & $\mathbf{L}$ & $\%$ & $\mathbf{M}$ & $\%$ & $\mathbf{H}$ & $\mathbf{L}$ & $\mathbf{L}$ & $\%$ & M & $\%$ & $\mathbf{H}$ & $\%$ \\
\hline Bore & 100 & 16.70 & 18.16 & 15 & 62.5 & 5 & 20.83 & 4 & 16.7 & 14 & 58.3 & 7 & 29.16 & 3 & 12.5 \\
\hline A.Sora & 100 & 17.48 & 23.63 & 19 & 67.85 & 6 & 21.42 & 3 & 10.7 & 20 & 71 & 6 & 21 & 2 & 7.14 \\
\hline Damma & 100 & 22.72 & 27.39 & 7 & 33.37 & 12 & 57.12 & 3 & 14.3 & 3 & 12 & 19 & 76 & 3 & 12 \\
\hline
\end{tabular}

Prev $=$ Prevalence, Inci $=$ incidence, $\mathrm{Sev}=$ Severity, $\mathrm{L}=$ low disease class designated $0 \_20 \%$ Incidence and Severity), $\mathrm{M}=$ medium disease class designated from $21-40 \%$ (Incidence and Severity), $\mathrm{H}=$ high disease class is greater than $41 \%$ (Incidence and Severity).

\subsection{Disease Severity}

Severity of wheat stem rust was recorded and found to vary from low to high at district and PA levels (Table 1 and 2 ). The highest average severity of $27.4 \%$ was recorded in Damma, followed by average severity of $22.8 \%$ at Ana Sora district (Table 2). The lowest severity both at district $(18.2 \%)$ and peasant association level $(9.5 \%)$ was recorded in Bore and lettu peasant association respectively. Severity was below $20 \%$ for majority PA's in Bore districts. Similarly, severity of the disease was between $15.1 \%-45 \%$ at PA level in Damma district. The overall wheat stem rust severity mean was $22.8 \%$ for the three districts in Guji zone indicating wheat stem rust was important in the all surveyed areas. Salman et al., (2006) reported that yield losses increase proportionately with an increase in severity of the disease. According to their investigations, varieties like Morocco, WL-711, SA75, SA42 and Chakwal exhibited maximum losses of $52-57 \%$ against the leaf rust. In all the survey areas of Guji zones wheat stem rust may reach the highest epidemic level if it get susceptible and late maturing cultivars along with favourable 
environmental conditions that for the pathogens.

\subsection{Date of Planting and Wheat Stem Rust}

Twenty-three $(29.80 \%)$ fields in surveyed area were planted in July and had a wheat stem rust incidence of $23.3 \%$ and severity of less than $15 \%$. On the other hand, 50 $(64.93 \%)$ fields in surveyed area were sown in August. Fields planted during this time had stem rust incidence of $28.05 \%$ and less than $25 \%$ of disease severity. Only 4 fields were planted in September. This had wheat stem rust incidence of greater than 30.6 and less than $30 \%$ disease severity. Based on these findings, it appeared that incidence of wheat stem rust was higher in August sown wheat fields than in July sown. Usually August sown wheat reach flowering or grain filling in November. This period usually coincides with warmer and humid weather (not sown) which favours growth, reproduction and spread of the rust pathogen. It may the most devastating and yield loss may greater $50 \%$ for rust disease in the case of early onset of the disease (Yaqoob, 1991). Losses of $100 \%$ can occur with susceptible cultivars. In the surveyed area both late and early sowing was practiced for the several reasons. Most of the farmers use early planting to escape their crops from frost damage and sometimes they also use for stem rust as it is happening in the area at the end of October. Late planting also practiced to minimizing the effect of rain that was happened at the time physiological maturity. Wheat stem rust is more important in late growing period, on late sown and late maturing cultivars.

Table 3. Planting date, disease incidence and severity for three districts of Guji zone during main season of 2011

\begin{tabular}{cccc}
\hline $\begin{array}{c}\text { Month of } \\
\text { planting }\end{array}$ & $\begin{array}{c}\text { Number of } \\
\text { fields }\end{array}$ & Incidence (\%) & Severity (\%) \\
\hline 25 July & 23 & $23.30 \pm 6.5$ & $12.88 \pm 4.25$ \\
01 August & 50 & $28.05 \pm 7.93$ & $24.00 \pm 10.17$ \\
01 September & 4 & $30.6 \pm 12$ & $28.00 \pm 15.4$ \\
\hline
\end{tabular}

\subsection{Cultivars Grown and Wheat Stem Rust}

The growers in the surveyed areas use five different kinds of wheat cultivars namely, local, Kubsa, Digalu, Merero, Kakaba. The most widely grown cultivar Kubsa occupied 39 (50.64\%) fields in the surveyed three districts of the zones. Local and Digalu follow Kubsa, each covering $31.5 \%$ and $9.5 \%$ of the surveyed fields, respectively. Merero and Kakaba cultivars were currently introduced by Bore Agricultural Research and they were under field evaluation on research plots and on farmers' fields. These two cultivars covers only $2.7 \%$ and $1.4 \%$ of the fields surveyed in the area, respectively. Incidence of wheat stem rust was greater than $23 \%$ in 39 (50.64\%) out of 77 fields sown with Kubsa and 19 fields out of 39 had greater than $25 \%$ of wheat stem rust severity indicating that this cultivar was attacked by the disease in most areas of the surveyed districts. Likewise, local was sown in 28 fields, of which 16 fields had wheat stem rust severity of greater than $25 \%$. In contrast, 7 fields were sown with cultivar digalu which had incidence less than $15 \%$, while only 3 fields $(3.89 \%)$ showed less than $10 \%$ severity of wheat stem rust in Bore district. The study showed that different levels of wheat stem rust incidence and severity was observed on different cultivars grown indicating that some cultivars were less affected by the disease than others; this may be due to the genetic makeup of cultivars which confer difference in resistance under different environmental condition to the Pgt (Table 4).

Table 4. Wheat stem rust incidence, severity by cultivars grown in the three districts of Guji zone during the main season of 2011

\begin{tabular}{ccccc}
\hline District & Cultivar & $\begin{array}{c}\text { Number of } \\
\text { field }\end{array}$ & $\begin{array}{c}\text { Incidence } \\
\text { (\%) }\end{array}$ & $\begin{array}{c}\text { Severity } \\
\text { (\%) }\end{array}$ \\
\hline Bore & Digalu & 7 & 15.7 & 12 \\
& Kakaba & 1 & 7.3 & 7.7 \\
& Kubsa & 10 & 28.70 & 30.85 \\
& Local & 4 & 33.3 & 32.15 \\
& Merero & 2 & 5.56 & 4.25 \\
\multirow{5}{*}{ Aana Sora } & Kubsa & 21 & 23.5 & 18.90 \\
& Local & 7 & 12.61 & 10.10 \\
& Kubsa & 8 & 23.4 & 23.36 \\
& Local & 17 & 29.8 & 24.43 \\
\hline
\end{tabular}

\subsection{Altitude and Wheat Stem Rust}

Simple regression analysis was done for disease incidence and severity as response and altitude as predictor variable showed that highly significant $(p<0.01)$ of the overall probability of the equation. For disease incidence and severity the fitted regression equation using at single model revealed that every $100 \mathrm{~m}$ increase in altitude at (flowering and maturity) in the surveyed areas resulted in reduction of incidence and severity by $0.033 \%$ and $0.030 \%$ respectively (not shown). The R-square value of the equation explained about $6.4 \%$ and $9 \%$ for disease incidence and severity respectively. This is low probable for disease incidence and severity altitude may not be a single major factor for the variation of wheat stem rust in the surveyed districts of the Guji zones. There should be other factor like favourable environmental condition and the level of host resistance grown also play a significant role.

\subsection{Fungicide Use and Wheat Stem Rust}

From 77 fields only 11 (14.28\%) fields were applied with fungicides once or twice in the growing season when stem and stripe rusts became prevalent in the area. Bayleton was the fungicide used for the control of rusts in the area. The incidence and severity of stem rust in the fields which did not use any of the fungicides was less than $23 \%$ and $22 \%$, respectively. In contrast to this, $11(14.28 \%)$ of the fields which use fungicides exhibited average incidence of less than $19 \%$ and severity of less than $12 \%$ for the three districts (Table 5). These findings showed that fungicides 
use in the surveyed area was not widely popular for the control of wheat stem rust and other rust disease. It is important for the grower to be able to identify the disease early; however, this is not always possible without relevant skills for the correct disease identification, and rust severity assessment that are prerequisite to informed decisions on fungicide use. Even in the sprayed fields, the incidence is almost the same as that of unsprayed fields in the surveyed area of the Guji zone. This might be because the farmer may start spraying too late when the disease has well established in the fields or neighboring fields. As it well known rust diseases are wind borne, so repeated applications and regular monitoring is indispensible because stem rust is easily introduced to the health fields from their neighboring by winds.

Table 5. Mean stem incidence and severity (\%) on fungicide sprayed and non-sprayed fields

\begin{tabular}{ccccccc}
\hline District & $\begin{array}{c}\text { Number } \\
\text { of fields }\end{array}$ & \multicolumn{2}{c}{ Sprayed field } & \multicolumn{2}{c}{ Non sprayed } \\
& & & $\begin{array}{c}\text { Incidence } \\
(\%)\end{array}$ & $\begin{array}{c}\text { Severity } \\
\text { (\%) }\end{array}$ & $\begin{array}{c}\text { Incidence } \\
\text { (\%) }\end{array}$ & $\begin{array}{c}\text { Severity } \\
(\%)\end{array}$ \\
\hline Bore & 6 & 18 & 13.67 & 13.3 & 23.0 & 22.1 \\
Ana & 4 & 24 & 16.4 & 11.4 & 18.1 & 18.5 \\
Sora & & & & & & \\
Damma & 1 & 24 & 26.3 & 10.5 & 26.45 & 23.5 \\
Total & 11 & 66 & 56.4 & 35.1 & 67.6 & 64.2 \\
Mean & - & - & 18.8 & 11.7 & 22.5 & 21.4 \\
\hline
\end{tabular}

\section{Conclusion and Summary}

Results from wheat rust survey in three Guji zones reveals that stem rust was prevalent everywhere wheat is grown during main and short rainy seasons with varying degree of incidence and severity. However, the disease prevalence was $100 \%$ in all of the surveyed area of the zones that means all surveyed peasant associations in districts were infected. The disease was severe in Damma district, even though with less than $30 \%$ of severity. Most probably in the near future the severity may increase because of very few improved cultivars that are susceptible to disease become common and no chemical control was practiced in the areas.

Bore district suffers least from stem rust threat. In this district use of improved cultivars and chemical spray was practiced better compared to other two districts. The study also indicated that fungicides were used only by few farmers, probable because of unaffordable prices, low access to get good and fresh fungicides and lack of awareness on how to use. On the other hand, 10 years weather data of the area showed that a moderately favorable environment for the development of stem rust prevalent in most of the districts. Generally in the Guji zones where survey were conducted 39 (50.64\%) and 28 $(36.36 \%)$ of the fields were planted by highly susceptible reaction Kubsa and local respectively. Few improved cultivars were recently introduced by Bore Agricultural Research Center for the enhancement of the wheat yield in the study area.

\section{References}

[1] Amanuel Gorfu. 1994. An analysis of long-term constraints to wheat production in Ethiopia .pp 35-39. In: D.G.Tanner (ed.) A Regional Travelling Workshop on Long Term Wheat -based Sustainability Trials in East Africa. A.A., Ethiopia: CIMMTY/CIDA EACP

[2] Belay Sime and Tanner D.G. 1999. Yield potential and weather risks associated with wheat production in Ethiopia. Proceedings of the Tenth Regional wheat Workshop of Eastern, Centeral and southern Africa. Addis Ababa, Ethiopia, pp 316-324.

[3] CSA. 2010. Crop production forecast sample survey. Report on Forecast of Area and production of Major Crops (for rural private peasant holdings). Statistical Bulletin 271: 1819

[4] Curtis, B.C., S. Rajaram. and H.G. Macpherson (eds.) 2002. Bread wheat Improvement and production No. 30. Food and Agriculture Organization of the United Nations, Rome Italy pp 554

[5] Leppik, E.E., 1970. Gene centers of plants as a source of disease resistance .Ann.Rev. Phytopathology 8:323-344.

[6] Park R.F., 2007. Stem rust of wheat in Australia. Australia Journal of Agricultural Research 58:558-566.

[7] Loegering, W.Q., C.O, Johnston and J.W, Hendrix, 1967. Wheat rusts. pp307 -337 In: Loegering .W.Q., R.A, McIntosh and Burton, C.H.(1971). Computer analysis of disease data to derive hypothetical genotypes for reaction of host varieties to pathogens. Can. J. Genetics. Cytol . 13: 742-748.

[8] Saari, E.E. and Prescott, J.M., 1985. World distribution in relation to economic losses. In: Roelfs A.P. and Bushnell W.R. (eds.) The Cereal Rusts Vol. II; Diseases, Distribution, Epidemiology and Control. Academic Press, Orlando. pp. 259-298.

[9] Salman, A., M.A. Khan and Mumtaz Hussain. 2006. Prediction of yield losses in wheat varieties/lines due to leaf rust in Faisalabad. Pak. J.Phytopathol., 18(2): 178-182

[10] Yaqoob, M. 1991. Study on rusts and tolerance in wheat cultivars in greed lines in Pakistan. M.Sc. Thesis, Department of Plant Pathology, University of Agriculture, Faisalabad, pp. 98 